\title{
PRESENT LEVEL OF KNOWLEDGE REGARDING FLUVIAL MACROINVERTEBRATE COMMUNITIES IN SPAIN
}

\author{
J. Alba-Tercedor ${ }^{1}$, G. Gonzalez ${ }^{2}$ and M.A. Puig ${ }^{3}$ \\ 1. Departamento de Biología Animal y Ecología. Facultad de Ciencias, Universidad de Granada. Spain. \\ 2. LIMNOS S.A..Bruc, 168. Barcelona 08037. Spain. \\ 3. Centro de Investigaciones del Agua. CSIC. La Poveda, 28500 Arganda del Rey, Madrid. Spain.
}

Keywords: River systems, Macroinvertebrates, History, Knowledge level. Spain

\begin{abstract}
A synthetic review examines present knowledge of fluvial macroinvertebrates in Spain. Many works have been strictly dcscriptive, and most have aimed at the application of biotic indices in water quality studies. Nevertheless, new awareness in the 1980s, fostered by the Spanish Association of Limnology, has begun to stir works that carry more profound implications regarding community ecology and lotic ecosystems.
\end{abstract}

\section{INTRODUCTION}

A knowledge of benthic macroinvertebrate communities is widely considered to be vital in understanding the ecology of waterways (MARGALEF, 1947, 1960). The principal necessity in developing the study of macrobenthic ecology is a good taxonomic knowledge of the different faunistic groups involved. In Spain two major problems exist. Firstly, a great diversity of species inhabit fluvial environments. and the role of the Iberian Peninsula as a refuge and/or dispersion zone at different geological moments has made the area faunistically very rich, with numerous endemic species (SANCHEZ-ORTEGA \& ALBA-TERCEDOR, 1987). Secondly, if in fact the number of taxonomists who work on these groups has increased, the number is still small, and in any case inadequate (VALDECASAS et al., 1990). One reason for this is the comparatively low value generally placed on taxonomy. For example, studies on the water quality of rivers, using more or less simple biotic indices, abound because of the great acceptability and social interest of this work. Consequently, we are currently reaching a paradox in which we have studied water quality in a good part of our waterways without knowing the composition of species inhabiting those environments.

In Spain a good index of the true situation surrounding faunistic knowledge is the publication of the faunistic lists and bibliographies of the different fluvial macrobenthic groups. Apart from works in preparation, to date there have been publications on Ephemeroptera (ALBA-TERCEDOR, 1981), Plecoptera (SANCHEZ-ORTEGA \& ALBATERCEDOR, 1987), Heteroptera (NIESER \& MONTES, 1984), Coleoptera (MONTES \& SOLER, 1986; RICO et al.. 1990; VALLADARES \& MONTES, 1991), Mollusca bivalvia (VIDAL-ABARCA \& SUAREZ, 1985), Hydrachnellae (VALDECASAS, 1988); and a preliminary list of chironomid Diptera (COBO et al., 1987).

In this work we present a general synthesis of current knowledge regarding sensu lato ecology of fluvial macroinvertebrates in Spain. For this we have included only those studies which involve macroinvertebrates as a whole, and therefore we have not considered those works that include only one or two faunistic groups, or those that contribute no information other than a list of taxa.

\section{HISTORY}

The beginning of the study of fluvial benthic communities can be traced to the works of MARGALEF (1947, 1948, $1949,1952,1953,1955,1960)$, which offer descriptions of communities $(1946,1948,1949,1952,1953,1955)$ as well as theoretical proposals for the stages in community development and for comparisons between fluvial and lacustrine systems (1947). Professor Margalef's role as founder and 
driving force of limnology in Spain is further demonstrated by the fact that his theories on the functioning and structure of fluvial systems (1960) have been and continue to be models for testing and generating alternative hypotheses. Nonetheless, there is a conspicuous time gap between the work of Margalef and subsequent studies by Spanish researchers. On examining the evolution of studies related to fluvial benthos (fig. 1). we find that published works begin to proliferate in the 1970s and especially at the beginning of the 1980s. coinciding with the foundation of the Spanish

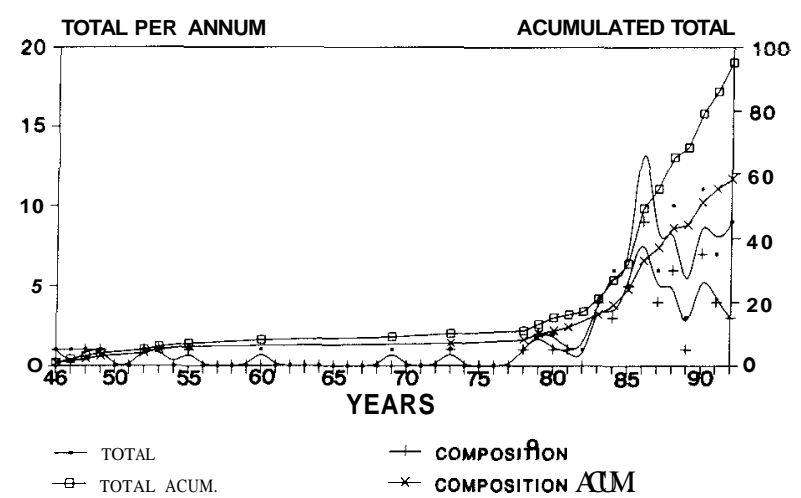

Figure 1. Spanm papes on flus ial macroinvertaballe communities (a) and species composition (b).

Association of Limnology. There were originally three areas of focus, due to the existence of relatively numerous groups: Barcelona, Granada and Madrid. Work in these areas, together with other groups appearing in different parts of the peninsula (Asturias, Basque Country, Murcia) has contributed to a knowledge of certain aspects of benthic communities partly from the hydrographic network of Spain. There are still many zones, however, where no studies on benthic communities have been published (fig. 2). In fact, some of the major hydrographic bodies (Ebro, Tajo and Guadiana Rivers) are still largely to be studied (fig. 3).

If we consider the temporal evolution of the publications (fig. 1), we can find a relationship between the convocations of the Spanish Association of Limnology (every two years) and the rate of appearance of the majority of the works published. The study of fluvial benthic communities reached its high point in 1986, after which, due to its complexity and the greater economic returns (though not scientific) of other approaches, such as water quality biology, interest flagged to some degree. During the last congress of the Spanish Association of Limnology, in September of 1991, there was a clear predominance of works concerned with different aspects of lentic ecosystems (reservoirs, lakes, etc.) (fig. 4).

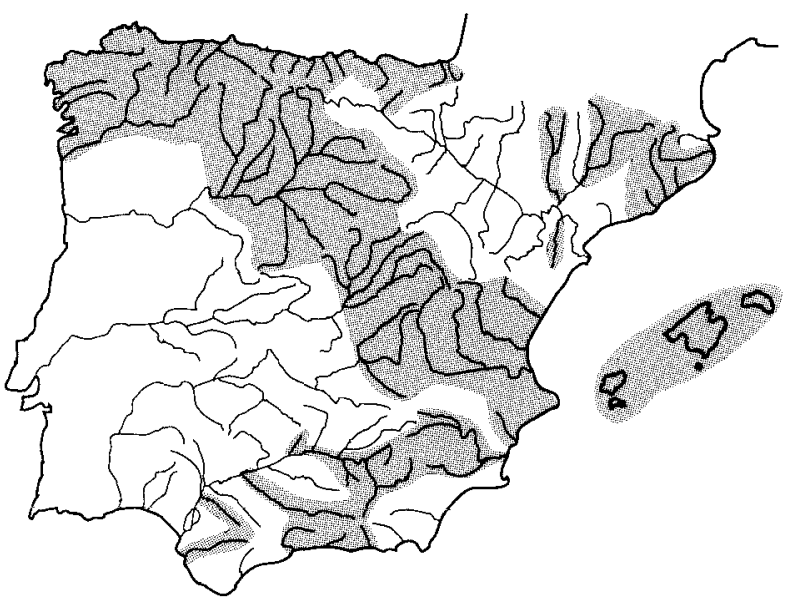

Figure 2. Location of the watew was prospected on macromvertebiate communttes studies.

Up to the present time, the different Spanish fluvial networks have been studied with varying intensity, as can be seen in fig. 5. Certain areas have received particular
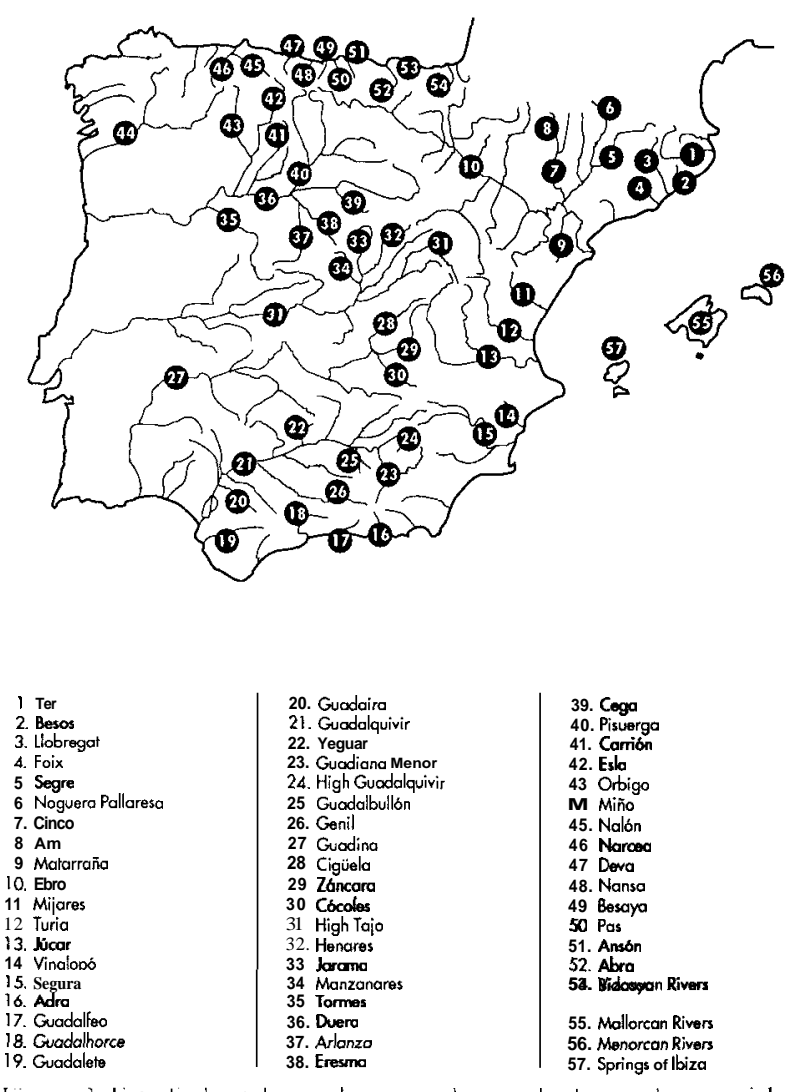

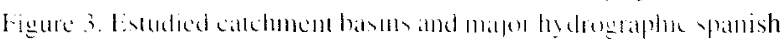
rivers. 
attention: Catalonian fluvial networks, with a total of 21 works published from the University of Barcelona (MARGALEF, 1948,1952,1953; PRAT et al., 1979-1986; MILLET \& PRAT, 1984; GONZALEZ et al., 1985; GROSSMAN et al., 1985; PALAU \& PALOMES, 1986 a,b; RIERADEVALL \& PRAT, 1986; PUIG et al., 1987-1990); the high Guadalquivir Basin (DOMEZAIN et al., 1987; ZAMORA-MUÑOZ, 1988; MADRID, 1990; UNIVERSIDAD DE GRANADA, 1990; ALBA-TERCEDOR et al., 1990-91; CASTILLO et al., 1991; ZAMORA-MUÑOZ, 1992; ZAMORA-MUÑOZ \& ALBA-TERCEDOR, 1992), together with small Mediterranean water courses in the provinces of Granada and Almeria(ALBA-TERCEDOR \& JIMENEZ-MILLAN, 1985; ALBA-TERCEDOR et al., 1986), with 14 published works from the University of Granada; the high basin of the Tajo River, with 8 works from the Autonomous and Polytechnic Universities of Madrid (GARCIA DE JALON, 1980; GONZALEZ DEL TANAGO \&GARCIA DE JALON, 1980, 1981; GARCIA DE JALON \& GONZALEZ DEL TANAGO, 1982; HERRANZ, 1983;CASADO, 1986; HERRANZ \& GONZALEZ DEL TANAGO, 1986; BALTANAS, 1990); and finally the Duero River Basin with a general study carried out by the Polytechnic University of Madrid (GONZALEZ DEL TANAGO \& GARCIA DE JALON, 1984; GARCIA DE JALON \& GONZALEZ DEL TANAGO, 1986; GARCIA DE JALON et al., 1986;) and with certain secondary water courses studied by the University of Leon (LUIS et al., 1986; MANZANERA \& ALVAREZ, 1987; PRESA et al., 1988). Furthermore, in the Cantabrian cornice the rivers of the following regions have been studied by the Universities of Oviedo (ABELLA \& GONZALEZ, 1986; ORTEGA, 1990) and the Basque Country (BARGOS \& MESANZA, 1988; PINKSTER, 1988; RALLO et al., 1988; IMBERT \& POZO, 1989; RODRIGUEZ \& WRIGHT, 1991; RICO et al., in press) and Water Research Authority of North-Spain (ARLUZIAGA \& ALZATE, 1984; LOPEZLLANEZA, 1984; GONZALEZ et al., 1986 a, b; MIRANDA, 1987).

As a group, the studies on fluvial benthos advance two principal themes: community structure (descriptive phase) and indices (biotic indices and water quality). In addition to these two areas of interest appear some studies on community zonation (cases associated with time) and some works presenting wider ecological proposals (MARGALEF, 1947, 1960; GARCIA DE JALON, 1980; HERRANZ, 1983; MILLET \& PRAT, 1984; CASADO, 1986; HERRANZ \& GONZALEZ DEL TANAGO, 1986; PRAT et al., 1986;
RIERADEVALL \& PRAT, 1986; PUIG et al., 1987: GARCIA DE JALON et al., 1988; FANLO et al., 1989; IMBERT \& POZO, 1989; BALTANAS, 1990; ORTEGA $e t$ al., 1991; PUIG et al., 1991; SOLER, 1991; MALO \& PUIG, 1992; PUIG, 1992; ROLDAN \& PUIG, 1992; SOLER \& PUIG, 1992). These distinct thematic areas, preferred by Spanish researchers, provide reference points in our effort to understand the present level of knowledge of fluvial benthos, as we shall discuss below.

\section{FLUVIAL MACROBENTHIC COMMUNITY STRUCTURE}

The first works known which explore the structure of macrobenthic fluvial communities had very particular aims. The majority of these studies were organized according to the relationships between species that make up the community, together with the community's relationship to either the physical structure of the habitat or the degree of water mineralization (MARGALEF, 1946, 1948, 1949, 1953). Between 1978 and 1983 (GONZALEZ DEL TANAGO, 1978; PRAT et al., 1979; GONZALEZ DEL TANAGO \& GARCIA DE JALON, 1981; GARCIA DE JALON \& GONZALEZ DEL TANAGO, 1982; PRAT et al., 1983) a series of studies appeared which were directed fundamentally at understanding the temporal changes that occur in macrobenthic communities and/or temporal development. The longitudinal distribution of the water courses was also discussed in some cases (GARCIA DE JALON \& GONZALEZ DEL TANAGO, 1982; HERRANZ, 1983; PRAT $e t$ al., 1983; ARLUZIAGA \& ALZATE, 1984; MILLET \& PRAT. 1984; ALBA-TERCEDOR \& JIMENEZ-MILLAN,

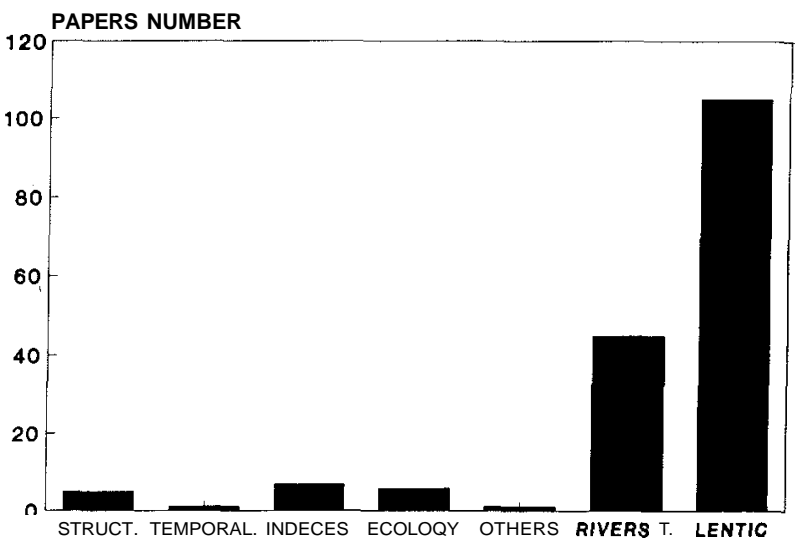

Figure 4. Distribution of papers oil tematic topics presented in the last Congress on Spanish Limnology (1991). 
1985; GONZALEZ et al.. 1985; ALBA-TERCEDOR et al., 1986; PRESA et al., 1988; ZAMORA-MUÑOZ, 1988).

Of the overall number of works we have compiled, 95, only $58(61.05 \%)$ offer information on the composition of these communities. This situation is primarily because. between 1984 and 1986, works were continued on known courses for which communities had already been described (Catalonia). Beginning in 1986, the year of the major work describing benthic communities (fig. 1), there was an appreciable decrease in the number of new works concerning the composition and structure of the Spanish fluvial benthic communities.

On carefully analysing the state of knowledge of this type of community composition we find that most studies focused on only a part of the problem and not always on the numerically predominant groups. In addition, studies of macroinvertebrate communities that include an identification of Diptera (especially the chironomids), at a level lower than the family, are an exception (PRAT et al., 1983, 1985; PUIG et al., 1984, 1987; RALLO et al., 1988; ROLDAN \& PUIG, 1992). For this reason, to provide a general characterization of the composition by taxa according to waterways, we have considered only the six groups that have been most thoroughly studied in most cases: Ephemeroptera, Trichoptera, Plecoptera, Coleoptera, Odonata and Heteroptera. On the basis of specific composition we have looked for tendencies, similarities and differences among fluvial courses which present different structural characteristics.

Various types of faunistic composition have been detected (fig. 6):

1. In the waterways of northeastern Spain (Cinca, Noguera Pallaresa. Ter. Llobregat. Besos, Foix and Mata-

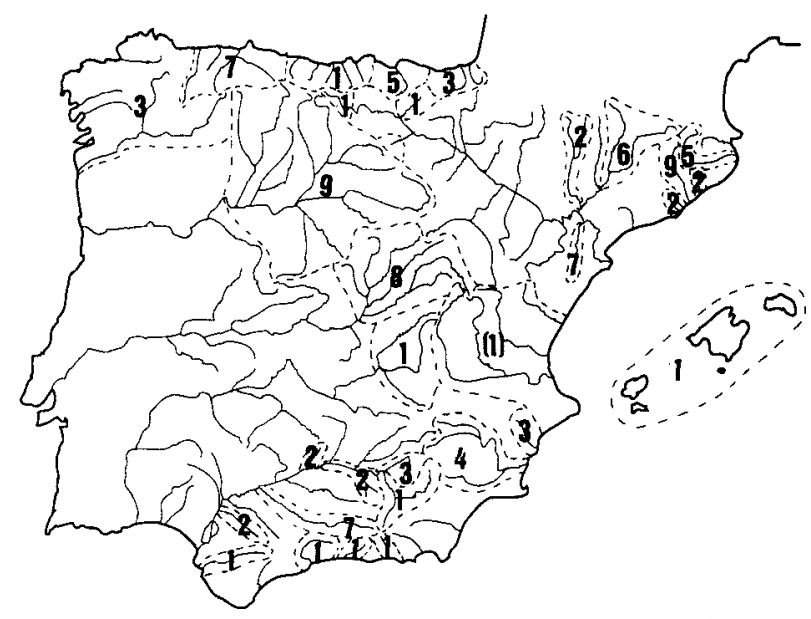

Figure 5. Numbira al piper published for firstly river basins. rraña Rivers). that is, the sub-basin of ihe Ebro River and the small Catalonian water courses north of the Fhor.

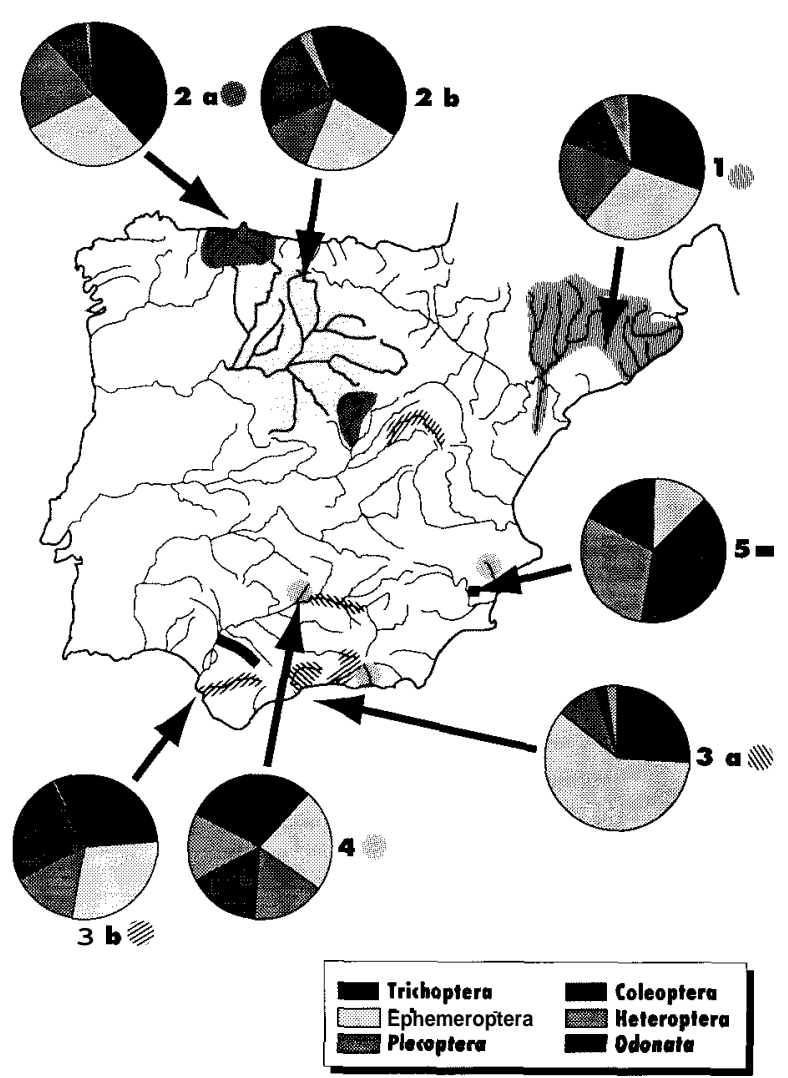

Figure 6. Types of faunistic composition detected in the spanish basins.

dominance is shared by Trichoptera and Ephemeroptera, with Plecoptera as an accompanying species. For the all of the orders combined, moreover, the reophile species constitute the largest part of the community (PRAT et al., 1983, 1985; GROSSMAN et al., 1985; PUIG et al., 1987; GARCIA DE JALON et al., 1988; PUIG et al., 1990; PUIG, 1992).

2. In waterways of the northwestern and central part of Spain (small Asturian courses, Nalón, Duero and Jarama Rivers), Trichoptera remains dominant, with Ephemeroptera as an accompanying group. But two subgroups are distinguishable on the basis of the second accompanying group: small courses with Plecoptera as the second accompanying order (Asturian rivers and the Jarama River) (GONZALEZ DEL TANAGO \& GARCIA DE JALON, 1981; GARCIA DE JALON \& GONZALEZ DEL TANAGO, 1982; LOPEZLLANEZA, 1984; ABELLA \& GONZALEZ, 1986); and 
large courses of generally little slope with Coleoptera as the second accompanying order (Duero River) (GARCIA DE JALON \& GONZALEZ DEL TANAGO, 1986).

3. In all of the permanent waterways in the southern half of Spain Ephemeroptera is the order with the greatest number of species. Two subgroups can be distinguished: courses in which only Ephemeroptera dominates (the medium-high stretch of the Guadalquivir River and the Guadalhorce River) (GARCIA DE JALON \& GONZALEZ DEL TANAGO, 1986; ALBA-TERCEDOR et al., 1990); courses with mountain systems, with Ephemeroptera and Coleoptera sharing dominance, and Trichoptera the basic accompanying group (sources of the Genil, Guadalete, Guadalfeo and Tajo Rivers) (ALBA-TERCEDOR \& JIMENEZ-MILLAN, 1985; ZAMORA-MUÑOZ, 1988; BALTANAS, 1990; GALLAR-DO, 1991; ZAMORA-MUÑOZ, 1992).

4. In seasonal waterways with permanent reophile stretches (Yeguas, Adra and Vinalopó River) no order appears to dominate having a very balanced representation of species belonging to Ephemeroptera, Trichoptera, Coleoptera, Odonata and Heteroptera. As a whole, lentic species dominate (GARCIA-ROJAS, 1985; ALBA-TERCEDOR et al., 1986; ROLDAN \& PUIG, 1992).

5. In completely seasonal waterways (Guadaira River and Moro Guich), systems resembling ponds more than rivers, lentic Coleoptera are clearly dominant (GALLARDO \& TOJA, 1988; ORTEGA, 1988; GALLARDO, 1991)

From the groupings of waterways according to community composition, a fairly dintinct typology can be identified, which might be completed in the future when the remaining Spanish fluvial systems have been studied. New data would be especially interesting Spanish fluvial systems have been studied. New data would be especially interesting from general studies of the major river such as the Ebro, Tajo, Guadiana and Guadalquivir, though stretches of some of these have been partialty investigated (Guadalquivir, Guadiana Menor).

\section{BIOTIC INDICES}

Of the works published on the benthos of Spain $47.37 \%$ concern water quality, and use macroinvertebrate as indices of pollution. These studies, which are still on the rise, have as their precedent the works of MARGALEF (1952, 1969). Not until the 1970 s, however, were any Spanish ideas effectively put into practice (GONZALEZ DEL TANAGO et al., 1979; PRAT et al., 1979), and in any case it should be mentioned that the first practica] experiment dealing with Spanish territory was carried out in 1973 by MEYNELL. The major development began in 1984 (fig. 7) and continued its crescendo until the present. Regarding this group of works we should point out that only few authors have used the saprobios system (SLADECEK, 1966; MARGALEF,

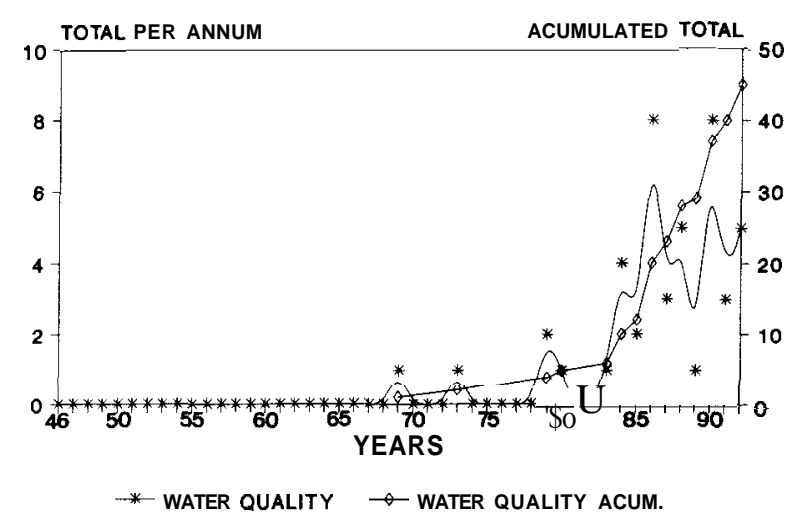

Figure 7. Spanish papers on biological pollution indicators (communities).

1969; GARCIA DE JALON \& GONZALEZ DEL TANAGO, 1986; VALDECASAS \& BALTANAS, 1990). In the rest of the works authors have tried to test and adapt different European indices (Vernaux and Tuffery, Chandler, BMWP system) (TUFFERY \& VERNEAUX, 1967; CHANDLER, 1970; ARMITAGE et al., 1983). There has been an obvious tendency toward obtaining maximum information with minimum effort. Leaving behind the inital use of biotic indices, which require the use of species identification (SLADECEK, 1966; TUFFERY \& VERNEAUX, 1967), researchers are at present in more or less general agreement on the use of the BMWP' (ALBA-TERCEDOR \& SANCHEZ-ORTEGA, 1988), an adaptation of the english BMWP (ARMITAGE et al., 1983) for the Iberian Peninsula, with quality guidelines which require the recognition of taxa at the family level only.

From the studies considered in this article, concerning both quality and any other perspective of fluvial macrobenthos for which the data allow the application of the BMWP' (GONZALEZ DEL TANAGO et al., 1979; GONZALEZ DEL TANAGO \& GARCIA DE JALON, 1980; GARCIA DE JALON \& GONZALEZ DEL TANAGO, 1982; PRAT et al., 1983; LOPEZ-LLANEZA, 1984; SOLER, 1984; ALBA-TERCEDOR \& JIMENEZMILLAN, 1985; GARCIA-ROJAS, 1985; GROSSMAN et al., 1985; PRAT et al., 1979; ALBA-TERCEDOR et al., 1986; CASADO, 1986; GARCIA DE JALON \& GONZA- 
LEZ DEL TANAGO, 1986; GONZALEZ et al., 1986A; PALAU \& PALOMES, 1986B; PRAT $\boldsymbol{e} t$ al., 1986; PUIG $\boldsymbol{e} t$ al., 1987,1990; GARCIA DE JALON $\boldsymbol{e} t$ al., 1988; RALLO et al.,1988; ZAMORA-MUÑOZ, 1988; ALBA-TERCEDOR et al., 1990; MADRID, 1990; ORTEGA, 1990; ALBATERCEDOR \& PICAZO, 1990, 1991; CASTILLO et al., 1991; GALLARDO, 1991; PUIG, 1992; ROLDAN \& PUIG, 1992; ZAMORA-MUÑOZ \& ALBA-TERCEDOR, 1992; MUÑOZ \& PRAT, in press), two maps have been drawn to synthesize the water quality of Spanish rivers. One map represents water quality during the summer (fig. 8) while the other indicates the average annual values from those works spanning more than one season (fig. 9). In fact, due to extent of the territory and the cartographic scale, it has not been possible to include in these maps all the sampling points included in the original works. For this reason the result must be intespreted as an approximation of the general situation (escecially when data was used from widely ranging years) for which partial works should be consulted to gain a more detailed interpretation of specific zones.

In most cases good biological conditions are found in unaltered communities, found only in stretches at the sour-

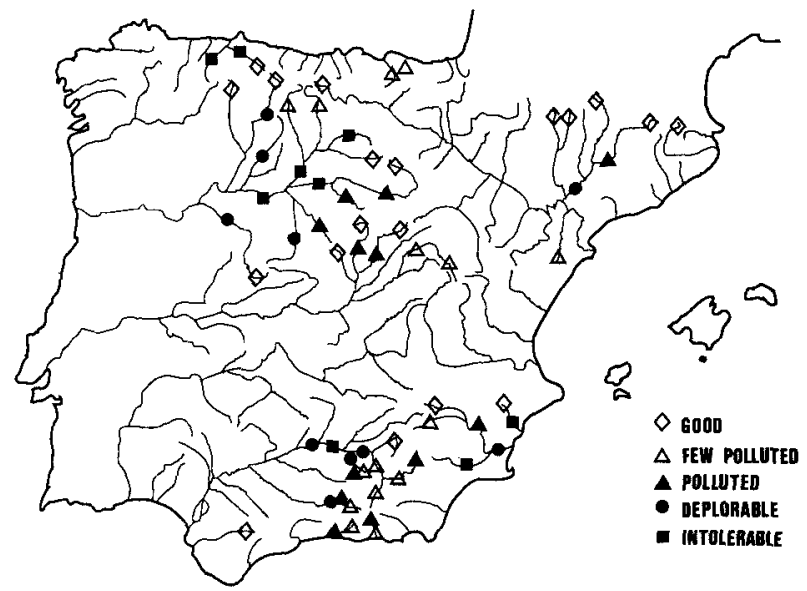

Figure 8 . Estimation of the water quality during summer.

ces of waterways and in waters above the effluents of population centers. Water quality deteriorates abruptly below effluent points, creating altered zones, with degrees of alteration in many stretches which can be classified as "critical" (deplorable) and "very critical" (intolerable). It is also necessary to point out that studies reated in successive years report a definite worsening of the situation (PRAT et al., 1983; ALBA-TERCEDOR \& PICAZO, 1990, 1991; MUÑ̃Z \& PRAT, in press).

\section{ZONATION OF FLUVIAL COMMUNITIES}

For the few works that have focused on the division os Spanish river communities into zones, we find two major tendencies. The first is the exhaustive cataloguing of different communities based on the zonation proposed by ILLIES \& BOTOSANEANU (1963). The best exponents of this approach in Spain have been GARCIA DE JALON \& GONZALEZ DEL TANAGO (1986), working in the Duero Basin. In addition, there have been other studies directed at a more restricted locations (GARCIA DE JALON \& GONZALEZ DEL TANAGO, 1982; ALBA-TERCEDOR et al., 1986). The second tendency is the consideration of the community structure of fluvial macroinvertebrates as being a longitudinal gradient of group and species substitution, in which the substitution hampers a clear division of the completely isolated macroinvertebrate communities characterizing precise stretches (VERNEAUX, 1973; VANNOTE, 1981). This approach uses different multivariant analyses (PCA and CCA), and has been the most used system since 1984 (GONZALEZ DEL TANAGO \& GARCIA DE JALON, 1981; GARCIA-ROJAS, 1985; GARCIA-AVILES, 1990).

Overall, the various studies published on zonation seem to indicate that the known Spanish fluvial systems allow us to differentiate their sources clearly, in contrast to the rest of the basin, where, strongly affected by the pollution in many cases, a gradient is found and therefore clear zonation is impeded (MILLET \& PRAT, 1984; PUIG et al., 1987, 1991), except perhaps the Duero Basin (GARCIA DE JALON \& GONZALEZ DEL TANAGO, 1986).

\section{SPECIAL SYSTEMS (CASES RELATED TO SEASONALITY)}

In spite of their singularity and their relative importance in Spanish geography, the seasonal rivers have not been considered important until the middle of the 1980s (GARCIA-ROJAS, 1985; GROSSMAN et al., 1985; PRAT et al., 1985, 1986; PUIG et al., 1986, 1991; GARCIAAVILES, 1990; ORTEGA et al., 1991; SOLER, 1991; ROLDAN \& PUIG, 1992; SOLER \& PUIG, 1992 ). Even since then work has been insufficient, producing only 10 finished studies. The results obtained up to now, however, have refuted two ideas: the concept that diversity in these systems is less than that of permanent waterways (GARCIA-ROJAS, 1985; PUIG et al., 1991); and the idea that the structures of these communities are homogeneus. 


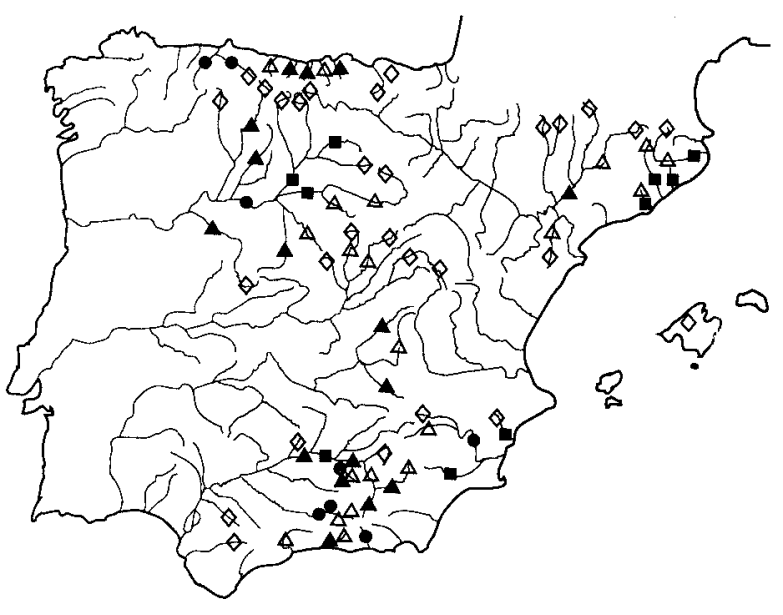

Figure 9. Average annual values of water quality (BMWP' used).

This latter concept can be rejected simply with the observation that seasonal river communities have been studied within three different typological groups defined in the section on community composition. Futhermore this subject is treated in depth in another chapter of this book.

\section{FUTURE PERSPECTIVES}

The tendency observed in the communications presented at the VI Spanish Congress on Limnology, showed the dominance of the works on biotic indices, although we can see a greater stant towards carrying our more complex studies on the community ecology of fluvial macrobenthos (fig. 4). Taken altogether, however, the number of works presented has been low (10.19\%), and therefore at present Spanish limnology is dominated by studies related to lentic systems, as opposed to those focused on lotic systems.

The needs involved in the study of the macroinvertebrate communities is Spain include the exploration of large waterways which are still completely unknown. This requires taxonomic work as a base. It must in fact approach a study of community ecology, scarcely begun and concentrated at the moment primarly on rates of colonization and displacement.

\section{REFERENCES}

ABELLA, M.A. \& M.J. GONZALEZ, 1986. Variación estaciona1 de la fauna dulceacuícola del Alto Nalón, Asturias. Lirnnética 2:173-179.
ALBA-TERCEDOR, J., 1981. Recopilación de citas de Efemerópteros en la Península Ibérica e Islas Baleares. Trah. Monogr. Dep. Zool. Univ. Granada 4 (2): 41-81.

ALBA-TERCEDOR, J., L.F. CAPITAN, M. ESPIGARES, C. COCA, I. GUISASOLA \& J.M. MARTIN, 1990. Estudio de las condiciones ecológicas, sanitarias, químicas y de calidad de las aguas de la cuenca media-alta del río Guadalquivir. Universidad de Granada, Granada. $428 \mathrm{pp}$.

ALBA-TERCEDOR, J. \& F. JIMÉNEZ-MILLAN, 1985. Evaluación de las variaciones estacionales de la calidad de las aguas del río Guadalfeo basada en el estudio de las comunidades de macroinvertebrados acuáticos y de los factores físico-químicos. ICONA Monografías 48: 11-91

ALBA-TERCEDOR, J. \& J. PICAZO, 1990. Calidad Biológica de las aguas de cauces de la margen izquierda de la Cuenca Alta del río Guadalquivir, Provincias de Granada y Jaén. I.A.R.A., Granada. 178 pp

ALBA-TERCEDOR, J. PICAZO, 1991. Calidad Biológica de las aguas de cauces de la margen izquierda de la Cuenca Alta del río Guadalquivir: Provincias de Granada y Jaén, II. I.A.R.A., Granada. 143 pp.

ALBA-TERCEDOR, J. \& N. PRAT, (in press). Spanish experience in the use of macroinvertebrate as biological pollution indicators. Actas International Conference on river water quality-ecological assessment and control.

ALBA-TERCEDOR, J. \& A. SANCHEZ-ORTEGA, 1988. Un método rápido y simple para evaluar la calidad biológica de las aguas corrientes basado en el de Hellawell (1978). Limnética 4: 51-56.

ALBA-TERCEDOR, J., A. SANCHEZ-ORTEGA \& I. GUISASOLA, 1986. Caracterización de los cursos permanentes de agua de la cuenca del río Adra: Factores físicoquímicos, macroinvertehrados acuáticos y calidad de las uguas. Universidad de Granada, Granada. 54 pp.

ANTELO, J.M., F. FERNANDEZ, M.R. SOLORZANO \& D. PRADO, 1990. Calidad de las aguas del río Anllons. Tecnologia del Agua 69.

ARLUZIAGA, I. \& J. ALZATE, 1984. Introducción a la ecología de los ríos guipuzcoanos. Lirnnética 1: 214-221.

ARMITAGE, P.D., D. MOSS, J.F. WRIGHT \& M.T. FURSE, 1983. The perfomance of a new biological water quality score system based on macroinvertebrates over a wide range of unpolluted running-water. Water Res. 17(3): 333-347.

ARMITAGE, P.D., I. PARDO, M.T. FURSE \& J.F. WRIGHT, 1990. Assessment and prediction of biological quality. A demonstration of a british macroinvertebratesbased method in two spanish rivers. Lirnnética 6: 147-156. 
BALTANAS, A., 1990. Estructura y organización de las comunidades de macroinvertebrados bentónicos del Alto Tajo: Escala, patrones aleatorios y perturbación. Tésis Doctoral, Universidad Autonoma de Madrid. 331 pp.

BARGOS, D. \& J.M. MESANZA, 1988. Variaciones estacionales de los grandes grupos taxonómicos de macroinvertebrados bénticos en la red hidrográfica de Bizkaia. Actas Il Congreso Mundial Vasco II: 97-110.

CASADO,C., 1986. Composición y estructura de las comunidades de macroinvertebrados de un rio intensamente regulado del Sistema Central: río Lozoya (Cuencadel Tajo). Tesis Doctoral, Universidad Autónoma de Madrid. 580 pp.

CASTILLO, A., J. ALBA-TERCEDOR, L.F. CAPITANVALLVEY, L. CRUZ-PIZARRO \& A. RAMOS, 1991. Ejemplo de un estudio interdisciplinar para la caracterización integral de la calidad y contaminación de las aguas de una cuenca de superficie. Actas III Simp. Agua Andalucía II: $277-288$.

COBO, F, M.JIMÉNEZ, J. CASAS, A. VILCHEZ, O. SORIANO, M. SEVILLANO, M. RIERADEVALL, I. MUÑOZ \& N. PRAT, 1987. Inventario faunístico de los quironórnidos conocidos de la Península Ibérica. Alquibla 12: 56-65.

CHANDLER, J.R., 1970. A biological approach to water quality rnanagement. Wat. Poll. Contr. 69: 415-422.

DOMEZAIN, A., I. GUISASOLA \& J. ALBA-TERCEDOR, 1987. Estudio de la incidencia de una piscifactoría en las comunidades de macroinvertebrados acuáticos. Limnética 3: 151-157.

FANLO, E., S. MITJANS, R. UBEDA, P. CASALS \& F. SOLEY, 1989. Influencia del sustrato en las comunidades de macroinvertebrados de los ríos del Moncayo. Turiaso 9: 597-616.

GALLARDO, I., 1991. Respuesta de macroinvertebrudos fluviales a la salinidad. Tésis de Doctorado, Universidad de Sevilla. 125 pp.

GALLARDO, A. \& J. TOJA, 1988. Efecto de la contaminación orgánica en los macroinvertebrados acuáticos en la cuenca del río Guadaira (Sevilla, SW España). Actas Col. Luso-Esp. Ecol. Bac. Hidrogr. e Rec. Zoologicas: 163-170.

GARCIA-AVILÉS, J., 1990. Insectos acuáticos de Baleares (Odonata. Ephemeroptera, Heteroptera, Plecoptera y Coleoptera). Tesis Doctoral, Universidad Cornplutense de Madrid. 690 pp.

GARCIA DE JALON, D., 1980. Efectos del Embalse de Pinilla (Madrid) sobre las comunidades de rnacroinvertebrados benticos del río Lozoya. Boletín Estación Central de Ecología 9: 47-52.
GARCIA DE JALON, D. \& M. GONZALEZ DEL TANAGO, 1982. Introducción a una zoosociología del rnacrobentos en los ríos de la Sierra de Guadarrama. Boletín de la Estación Central de Ecología 11(21): 63-71.

GARCIA DE JALON, D. \& M. GONZALEZ DEL TANAGO, 1986. Métodos biológicos para el estudio de la calidad de las aguas. Aplicación a la cuenca del Duero. ICONA, Madrid. 241 pp.

GARCIA DE JALON, D. \& M. GONZALEZ DEL TANAGO, 1986. Efemeroptera, Plecoptera y Trichoptera de los principales ríos de Malaga. Actas Simposium el Agua en Andalucía: 331-346.

GARCIA DE JALON, D., M. GONZALEZ DEL TANAGO, E. BARCELO, C. MONTES, F. MENES \& C. CASADO, 1986. Contribución al estudio faunístico de algunas taxocenosis de insectos acuáticos (Ephemeroptera, Plecoptera, Trichoptera, Coleoptera y Heteroptera) del Parque Natural del Lago de Sanabria y Río Tera (Zamora). Actas de las VIII Jornadas As. esp. Limn. 1.145-1 156.

GARCIA DE JALON, D., C. MONTES, E. BARCELO, C. CASADO \& F. MENES, 1988. Impacto ecológico de la regulación hidroeléctrica en ríos del Pirineo aragones. Actas del Congreso I/ Congreso Mundial Vasco 2: 140-162.

GARCIA DE JALON, D., C. MONTES, C. CASADO \& F. MENES, 1988. Effects of hydroelectric scherne on fluvial ecosystems within the spanish pyrenees. Reguluted Rivers 2: 479-491.

GARCIA-ROJAS, A.M., 1985. Estudio de los insectos acuáticos del río Yeguas. Tesina de Licenciatura, Universidad de Córdoba. 231 pp.

GONZALEZ, F., A. ALVAREZ-BRYLLA, A. MIRANDA, J.R. ALONSO \& M.A. ABELLA, 1986 a. Estudio comparativo de la calidad del agua en dos ríos asturianos. Limnética 2: 217-223.

GONZALEZ, F., A. ALVAREZ-BRYLLA, A. MIRANDA, J.R. ALONSO \& M.A. ABELLA, 1986 b. La calidad del agua en la cuenca del rio Piloña (Asturias). Limnética 2: 225-234.

GONZALEZ, G., X. MILLET, M.A. PUIG \& N. PRAT, 1985. Patterns of the macroinvertebrate distribution in the Llobregat river Basin (NE-Spain). Verh. inter. Verein. Limnol. 22(4): 2081-2086.

GONZALEZ, M.C., M.P. LANZA, M.P. ALVAREZ \& Y. PRESA, 1986. Análisis de los macroinvertebrados bentónicos y su helinintofauna en el río Porrna (León, NO España). Limnética 2: 181-187.

GONZALEZ DEL TANAGO, M., 1978. Ephemeroptera, Odonata y Plecóptera del Coto Nacional de las Sierras de 
Cazorla y Segura. Tésis Doctoral, Universidad Politécnica de Madrid. 172 pp.

GONZALEZ DEL TANAGO, M. \& D. GARCIA DE JALON, 1980. Estimación de la contaminación de las aguas mediante indicadores biológicos: Aplicación al río Jarama. Icona, Madrid. $156 \mathrm{pp}$.

GONZALEZ DEL TANAGO, M. \& D. GARCIA DE JALON, 1981. Estudio de la estructura biotipológica del río Jarama. Boletín de la Estación Central de Ecología 19: 33-51. GONZALEZ DEL TANAGO, M. \& D. GARCIA DE JALON, 1984. Desarrollo de un índice biológico para estimar la calidad de las aguas de la Cuenca del Duero. Limnética 1: 263-272.

GONZALEZ DEL TANAGO. M. \& D. GARCIA DE JALON, 1989. Elaboración y aplicación de índices biológicos. In: W. Lockhart (ed.), Proceedings of the first Symp. on the study, conservation and rational use of Salmonidae Fisheries, pp. 65-81. Madrid.

GONZALEZ DEL TANAGO, M., D. GARCIA DE JALON \& I.M. ELCORO, 1979. Estudio sobre la fauna de macroinvertebrados de los ríos Cigüela, Zancara y Corcoles: Aplicación de indices biológicos para el estudio de la calidad de sus aguas. Boletín de la Estación Central de Ecología 8(15): 45-59.

GROSSMAN, G.D., A. DE SOSTOA, J. LOBONCERVIA \& M.A. PUIG, 1985. Ecological-environmental relationships in some Río Matarraña fish assemblages. Comité Hispano-Norteamericano de Cooperación Científica y Técnica, Madrid. Interna1 Repport, 46 pp.

HERRANZ, J.M., 1983. Estudio de la fauna macroinvertebrada de la cuenca del Alto Tajo. Tésis Doctoral, Universidad Politécnica de Madrid. 464 pp.

HERRANZ, J.M. \& M. GONZALEZ DEL TANAGO, 1986. La colonización de sustratos artificiales por macroinvertebrados benticos en las aguas del Alto Tajo. Comparación de métodos de muestreo. Limnética 2: 163-171.

ILLIES, J. \& L. BOTOSANEANU, 1963. Problemes et méthodes de la classification et de la zonation écologique des eaux courantes, considerées surtout du point de vue faunistique. Mitt. int. Verein. theor. angew. Limnol. 12: 1-57.

IMBERT, J.B. \& J. POZO, 1989. Breakdown of four leaf litter species and associated fauna in a Basque Country forested stream. Hydrobiologia 182: 1-14.

LATORRE, E., 1987. La fauna de artrópodos acuáticos de la cuenca del río Razón (Soria). Tésis Doctoral, Universidad Complutense de Madrid. 160 pp.

LOPEZ-LLANEZA, J., 1984. Estudio de la calidad del agua en el río Nalón y su cuenca. Consejería de Ordena- ción del Territorio, Vivienda y Medio Ambiente, Oviedo. $127 \mathrm{pp}$.

LUIS, E., V. ABAD, E. BAYON. F. FERNANDEZ, A. GUTIERREZ, A. HERNANDEZ, C. POLANCO \& M.M. POSTIGO, 1986. Calidad estival de las aguas en los ríos influenciados por la ciudad de León. Importancia de bioindicadores artrópodos. Actas de las VIII Jornadas Aso. esp. Limn.: 1167-1178.

MADRID, F., 1990. Factores ,físico-químicos y comunidudes de macroinvertebrados de la cabecera del Río Genil (Sierra Nevada), aguas arriba de Granada. Estudio de la calidad biológica de sus aguas. Tesina de Licenciatura, Universidad de Granada. 198 pp.

MALO, J. \& M.A. PUIG, 1992. Efecto de las fluctuaciones sobre la estabilidad de la comunidad bentónica en un tramo permanente de un cauce mediterráneo (Río Matarraña, Cuenca del R. Ebro). Actas VI Congreso As. esp. Limnología.

MANZANERA, M.A. \& M.P. ALVAREZ, 1987. Estudio de las comunidades de macroinvertebrados bentónicos y su helmintofauna en un tramo del río Omañas (León, NO. de España). Limnética 3: 133-139.

MARGALEF, R., 1946. Contribución al conocimiento hidrobiológico del país vasco-navarro. In: Margalef, R., M.R. de San Miguel \& J. Rodríguez-Roda (eds.) Aportaciones al estudio de la fauna y flora vasco-navarras (Siera de Aralar). CSIC, Zaragoza.

MARGALEF, R., 1947. Limnosociología.Monografías de Ciencias Modernas, Madrid. 93 pp.

MARGALEF, R., 1948. Flora, fauna y comunidades bióticas de las aguas dulces del Pirineo de la Cerdaña. Monogr. Est. Pirenáicos 11.

MARGALEF, R., 1949. Datos para la hidrobiología de la Sierra de Guadarrama. P.Ins. Biol. Apl. 6: 5-21.

MARGALEF, R., 1952. La vida en las aguas dulces de Andorra. Actas del Primer Congreso Internacional del Pirineo : 5-107.

MARGALEF, R., 1953. Algunos organismos interesantes de las aguas dulces de los Pirineos. P. Ins. Biol. Apl. 28: 407-420.

MARGALEF, R., 1955. Comunidades bióticas de las aguas dulces del noroeste de España. P. Inst. Biol. Apl. 21: 5-85.

MARGALEF, R., 1960. Ideas for a synthetic approach to the ecology of running waters. Int. Revue ges. Hydrohiol. 45: 133-153.

MARGALEF, R., 1969. El concepto de polución en limnología y sus indicadores biológicos. Documentos Inv. Hidrol. 7: 103-133. 
MEYNELL, P.J., 1973. A hydrobiological survey of a small Spanish river grossly polluted by oil refinery and petrochemical wastes. Freshwat. Biol. 3: 503-520.

MILLET, X. \& N. PRAT, 1984. Las comunidades de macroinvertebrados a lo largo del río Llobregat. Limnéticu 1: 222-233.

MIRANDA, A., 1987. Utilización de macroinvertebrados bénticos como indicadores biológicos de la calidad del agua en el río Viao-Piloña (Asturias). Limnética 3: 141-150.

MONTES, C. \& A.G. SOLER, 1986. Lista faunística y bibliográfica de los coleópteros acuáticos Dryopoidea (Dryopidae \& Elmidae) de la Península Ibérica e Islas Baleares. Asociación española de Limnología. 38 pp.

MUÑOZ, I. \& N. PRAT (in press). Cambios en la calidad del agua de los ríos Llobregat y Cardener en los últimos diez años. Tecnología del Agua.

NIESER, N. \& C. MONTES, 1984. Lista faunística y Bibliográfica de los Heterópteros acuáticos (Nepomorpha \& Gerromorpha) de España y Portugal. Asociación española de Limnología. 66 pp.

ORTEGA, C., 1990. La calidad del agua en la red fluvial de Cantabria. Tésis Doctoral, Universidad de Oviedo. 496 pp.

ORTEGA, M., 1988. La Rambla del Moro (Cuenca del Río Segura). Ambiente físico, biológico y alteraciones producidas por una riada. Tesina de Licenciatura, Universidad de Murcia. $224 \mathrm{pp}$.

ORTEGA, M., M.L. SUAREZ, M.R. VIDAL-ABARCA, R. GOMEZ \& L. RAMIREZ-DIAZ, 1991. Aspects of postflood recolonization of macroinvetebrates in a "Rambla" of South-East Spain ("Rambla del Moro": Segura River Basin). Verh. Internat. Verein. Limnol. 24: 1994-2001.

PALAU, A. \& A. PALOMES, 1986 a. Los macroinvertebrados bentónicos como elementos de juicio para la evaluación de la calidad biológica del río Segre (Lerida, España). Limnética 2: 205-215.

PALAU, A. \& A. PALOMES, 1986 b. Diagnóstico físicoquímico y biológico del río Segre. Escuela Técnica Superior de Ingenieros Agrónomos, Lerida. 500 pp.

PINKSTER, S., 1988. Changes in the condition of basque rivers during the last 15 years. Actas II Congreso Mundial Vasco II: 133-143.

PRAT, N., M.I. BAUTISTA, G. GONZALEZ \& M.A. PUIG, 1979. Els cursos d'aigua. In: R. Folch (ed.) Elpatrimoni natural d'Andorra, pp. 261-309. Ketres, Barcelona. 446 pp.

PRAT, N., G. GONZALEZ \& X. MILLET, 1986. Comparación critica de dos índices de calidad del agua: ISQA y BILL. Tecnología del Agua 31: 33-49.
PRAT, N., G. GONZALEZ, X. MILLET \& M.A. PUIG, 1983. Chironomid longitudinal distribution and macroinvertebrate diversity along the river Llobregat (NE Spain). Mem. Amer. Ent. Soc. 34: 267-278.

PRAT, N., G. GONZALEZ, X. MILLET \& M.A. PUIG, 1985. El Foix entre l'eixutesa i la contaminació. Servei del Medi Ambient, Diputació de Barcelona. 92 pp.

PRAT, N., G. GONZALEZ, I. MUÑOZ \& X. MILLET, 1986. Community structure and colonization process in a mediterranean drainage basin. Proceedings of the 3rd European Congress of Entomology: 121-124.

PRAT, N., M.A. PUIG \& G. GONZALEZ, 1983. Predicció i control de la qualitat de les aigües dels rius Besós $i$ Llobregat, II: El poblament faunístic i la seva relació amb la qualitat de les aigües. Servei del Medi Ambient, Diputació de Barcelona. 164 pp.

PRAT, N., M.A. PUIG, G. GONZALEZ, M.J. TORT \& M. ESTRADA, 1983. The Llobregat: A mediterranean river fed by the Pyrenees. In: B.A. Whitton (ed), Ecology of european rivers. pp. 527-552. Blackwell, London. 644 pp.

PRESA, Y., E. LUIS \& J. SOTO, 1988. Consideración de los macroinvertebrados en la zonación de la cuenca del río Orbigo (León). Actas del Il Congreso Mundial Vasco 2: 207-215.

PUIG, M.A., 1992. Relaciones tróficas de la comunidad de macroinvertebrados en el río Matarraña (Cuenca del Ebro). Actas VI Congreso As. esp. Limnología.

PUIG, M.A., M. ABOAL \& A. DE SOSTOA, 1991. New approaches to mediterranean fluvial communities. Oecología aquática 10.

PUIG, M.A., J. ARMENGOL, G. GONZALEZ, J. PEÑUELAS, S. SABATER \& F. SABATER, 1987. Chemical and biological changes in the Ter River induced by a series of reservoirs. In: J.F. Craig \& J.B. Kemper (eds) Regulated Streams: Advances in Ecology. pp. 373-382. Plenum Press, New York. 421 pp.

PUIG, M.A., M. FERRERAS-ROMERO \& A.M. GARCIA-ROJAS, 1986. Ecosistemas de ríos temporales: ecología de las poblaciones de efemerópteros de la cuenca del río Bembezar (Sierra Morena). Anales de Biología 8: 65-69.

PUIG, M.A., G. GONZALEZ \& L. RECASENS, 1987. Módelos de distribución de Plecópteros, Efemerópteros, Tricópteros y Simúlidos en el río Ter. Limnética 3: 125-132.

PUIG, M.A., G. GONZALEZ \& O. SORIANO, 1984. Introducción al estudio de las comunidades de los ríos asturianos: Efemerópteros, Plecópteros, Tricópteros, Simúliidos y Quironómidos. Limnética 1(1): 187-196. 
PUIG, M.A., J. MALO, F. CASALS, M. ABOAL, D. VINYOLAS \& A. DE SOSTOA, 1990. Comunidades acuáticas de la Noguera Pallaresa: estado actual y cambios asociados a la gestión hidroeléctrica de los cauces. (PIE 121.43). Barcelona. $158 \mathrm{pp}$.

RALLO, A., M.A. SEVILLANO, M. OJEA, E. RICO, L. DOCAMPO \& J.C. ITURRONDOBEITIA, 1988. Niveles d calidad del agua en las distintas cuencas fluviales vizcainas: Clasificación obtenida por estudio faunístico de diversos taxones animales y en dos épocas del año. Actas II Congreso Mundial Vasco II: 217-222.

RICO, E., L.C. PEREZ \& C. MONTES, 1990. Lista faunística y bibliográfica de los Hydradephaga (Coleoptera: Haliplidae, Hygrobiidae, Gyrinidae, Noteridae, Dytiscidae) de la Península Ibérica e Islas Baleares. Asociación española de Limnología. 216 pp.

RICO, E., A. RALlO, M.A. SEVILlANO \& M.L. ARRETXE, (in press). La calidad de las aguas de las redes fluviales de Alava y Guipuzcoa (N. España). Estudio comparado de diversos índices biológicos. Annales de Limnologie.

RIERADEVALL, M. \& N. PRAT, 1986. Deriva nictemeral de macroinvertebrados en el río Llobregat (Barcelona). Limnética 2: 147-156.

RODRIGUEZ, P. \& J.F. WRIGHT, 1991. Description and evaluation of a sampling strategy for macroinvertebrate communities in Basque rivers (Spain). Hydrobiologia 213: 113-124.

ROLDAN, A. \& M.A. PUIG, 1992. Influence of aquatic invertebrate on the aquatic hyphomycetes occurring on leaves in a Mediterranean stream. Annales de Limnologie.

SANCHEZ-ORTEGA, A. \& J. ALBA-TERCEDOR, 1987. Lista faunística y bibliográfica de los Plecópteros (Plecoptera)de la Península Ibérica. Asociación española de Limnología. 133 pp.

SLADECEK, V., 1966. Water quality system. Verh. Intern. Verein. Limnol. 16: 809-816.

SOLER, A. (ED.), 1984. Estudios y directrices para el Saneamiento del Río Segura. Comunidad Autónoma de la Región de Murcia, Murcia. 473 pp.

SOLER, G., 1991. Pautas de migración de las comunidades bentónicas del río Matarraña (Cuenca del Ebro) a lo largo de un ciclo anual y en función de la velocidad de la corriente y la heterogeneidad del sustrato colonizable. Tesina de Licenciatura, Universidad de Murcia. 91 PP.

SOLER, G. \& M.A. PUIG, 1992. Similitud y diferencias de las pautas de colonización en tramos permanentes y temporales de un río mediterráneo (R. Matarraña, Cuenca del Ebro). Actas VI Congreso As. esp. Limnología.

TUFFERY, G. \& J.Q. VERNEAUX, 1967. Une metode zoologique practique de determination de la qualité biologique des eaux courantes. Indices biotiques. Ann. Scient. Univ. Besaçon zoologie 3: 79-90.

UNIVERSIDAD DE GRANADA, 1990. Caracterización físico-químico-biológica de las aguas del Alto Genil. Estudio Integral de la calidad y contaminación de las aguas. Universidad de Granada, Granada. 278 pp.

VALDECASAS, A., 1988. Lista sinonímica y bibliográfica de las Hidracnelas (Acari,Hydrachnellae) de la Península Ibérica, Islas Baleares e Islas Canarias. Asociación española de Limnología. 81 pp.

VALDECASAS, A. \& A. BALTANAS, 1990. Jacknife and bootstrap estimation of biological index of water quality. Wat. Res. 24(10): 1279-1283.

VALDECASAS, A., E. BELLO, E. REYES \& J. BECERRA, 1990. DIRTAX: A taxonomist database. Science Software 5(4): 303-308.

VALLADARES, L.F. \& C. MONTES, 1991. Lista faunística y bibliográfica de los Hydraenidae (Coleoptera) de la Península Ibérica e Islas Baleares. Asociación española de Limnología. 93 pp.

VANNOTE, R.L., G.M. MINSHALL, K.W. CUMMINS, J.R. SEDELL \& C.E. CUSHING, 1981. The river continuum concept. Can. J. Fish. Aquat. Sci. 37: 130-137.

VERNEAUX, J., 1973. Recherches écologiques sur le réseau Hydrographique du Doubs. Essai de biotypologie. Ann. Sc. Univ. Besançon 9: 1-260.

VIDAL-ABARCA, C. \& M.L. SUAREZ, 1985. Lista faunística y bibliográfica de los moluscos (Gastropoda \& Bivalvia) de las aguas continentales de la Península Ibérica e Islas Baleares. Asociación española de Limnología. 190 pp.

ZAMORA-MUÑOZ, C., 1988. Caracterización y calidad de las aguas del río Monachil (Sierra Nevada, Granada). Factores físico-químicos y comunidades de macroinvertebrados acuáticos. Tesina de Licenciatura, Universidad de Granada. 173 pp.

ZAMORA-MUÑOZ, C., 1992. Macroinvertehrados acuáticos, caracterización y calidad de las aguas de los cauces de la cuenca alta del Río Genil. Tésis Doctoral, Universidad de Granada. $255+109$ pp.

ZAMORA-MUÑOZ, C. \& J. ALBA-TERCEDOR, 1992. Caracterización y calidad de las Aguas del río Monachil (Sierra Nevada, Granada). Factores físico-químicos y comunidades de macroinvertebrados acuáticos. Junta de Andalucia, Agencia del Medio Ambiente, Granada. 